\title{
Islamic Higher Education Branding in The Coastal Area Perspective of Hermawan Kartajaya's PDB Triangle Theory
}

\author{
Sholikah \\ Institut Agama Islam Nahdlatul Ulama Tuban, Indonesia \\ sholihah_86@gmail.com \\ Fatah Syukur \\ UIN Walisongo Semarang, Indonesia \\ fsyukur@gmail.com \\ Mahfud Junaedi \\ UIN Walisongo Semarang, Indonesia \\ mjunaedi@gmail.com
}

\begin{abstract}
This article is a research on brand building strategies in private Islamic colleges in coastal areas, namely the IAINU Tuban and the IAI TABAH Lamongan. The purpose of this study is to analyze the strategies of Islamic colleges in coastal areas in building their institutional brands. This research is a case study using a descriptive qualitative approach. The results of this study are the strategies used by IAINU and IAI TABAH in building a brand in accordance with Hermawan Kertajaya's PDB Triangle strategy: 1) Positioning is clarifying campus icons; 2) Differentiation is making the campus characteristic, IAINU Tuban as a religious social entrepreneur campus and having the character of ahlussunnah wal jama'ah an nahdhiyah. Meanwhile, IAI TABAH Lamongan as a center for the development of Islamic science and competitiveness; 3) Brand is making the motto of each institution. The IAINU Tuban brand is a religious social entrepreneur, and the IAI TABAH brand is superior, religious, competitive.
\end{abstract}

Keywords: Branding Institution, Hermawan Kartajaya's PDB Triangle Theory 


\begin{abstract}
Abstrak
Artikel ini merupakan penelitian tentang strategi membangun brand di Perguruan Tinggi keagamaan Islam Swasta di wilayah pesisir yaitu IAINU Tuban dan IAI TABAH Paciran Lamongan. Tujuan penelitian ini adalah menganalisa strategi perguruan tinggi Islam di wilayah pesisir dalam membangun brand institusinya. Penelitian ini merupakan studi kasus dengan menggunakan pendekaatan kualitatif deskriptif. Hasil dari penelitian ini adalah strategi yang digunakan oleh IAINU Tuban dan IAI TABAH dalam membangun brand sesuai dengan strategi PDB Triangle Hermawan Kertajaya, yaitu: 1) Positioning, yaitu memperjelas icon kampus; 2) Diferensiasi, yaitu membuat ciri khas kampus, yaitu IAINU Tuban sebagai kampus religious social enterpreneur dan berkarakter ahlus sunnah wal jama'ah an nahdhiyah. Sedangkan IAI TABAH Kranji Paciran Lamongan sebagai pusat pengembangan ilmu keislaman dan berdaya saing; 3) Merek, yaitu membuat motto masing-masing institusi. Brand IAINU Tuban yaitu religious social enterpreneur, dan brand IAI TABAH yaitu unggul, religious, berdaya saing.
\end{abstract}

Kata Kunci: Branding Institusi; PDB Triangle Hermawan Kertajaya

\title{
A. Introduction
}

Higher Education has the autonomy to manage their own institutions as centers for the administration of higher education, scientific research, and community service (Article 24 paragraph 2, Government Regulation No. 17 of 2010). Enforcement of autonomy in educational institutions one of which is the authority given to higher education institutions to develop institutions, Malik Fajar (2004: 9) revealed that: "Since the reformation, universities have autonomy to develop themselves, including how to go public to the community or its stakeholders clearly."

This view requires the managers of higher education to innovate and try to develop the institutions they lead so that they can become better. In general managing higher education is identical to managing business organizations, which must always adjust customer demands (Imam Suprayogo, 2006: 154). The important thing to note in meeting stakeholder demands is to build a good reputation, and the results of the study show that stakeholders prefer to choose a reputable organization (The Offical MIM Academy Coursebook, 2010: 3). One important aspect in building an organization's good reputation is by building a positive impression in the eyes of stakeholders, where a positive impression in the context of marketing can be built through branding institutions. 
An institutional brand is a crucial element that contributes greatly to the success of an organization, both business and non-profit organizations (Fandy Tjiptono, 2005: 2). The era of globalization and the rapid development of the world economy has provided an indication of the importance of increasing branding and brand management (Marrs, Rachel, Musa, 2011: 964). In the 21 st century, every marketer of business organizations needs a special skill that is very important, namely the ability to build and manage brands. (Philip Kotler and Gary Armstrong, 2010) In a business context, a brand functions as an asset that is not clearly visible but has the highest value, able to represent the essence of an organization, as a very strong differentiator (powerful differentiator) for an organization and as a tool for make decisions for stakeholders (Aaker, 2010).

In the global era, business branding is not limited to traditional products, various service industries have tried to use branding strategies to build a stronger organizational brand (Marrs, Rachel, Musa, 965). So, in this case universities as part of non-profit service organizations, need to realize the importance of branding value and the need to build strong and sustainable branding institutions. The current global condition has an impact on tertiary institutions, so branding is a strategic issue for tertiary institutions in developing the meaning of brand differentiation of each tertiary institution to communicate its strengths (Jevons, 466467).

IAI Nahdhatul Ulama Tuban (hereinafter referred to as IAINU) is one of the private Islamic universities in the Coastal Area which has a stable number of students according to the ratio of lecturers to students and is in great demand by stakeholders even though the location of the campus is in the city and is in the environment of formal institutions. under the auspices of the National Education Office. At the beginning of its establishment, this institution had the name STIT Makhdum Ibrahim (STITMA Tuban) which was established under the auspices of PCNU Tuban. In 2019, this institution changed its form to the Nahdhatul Ulama Islamic Religious Institute (IAINU) for institutional development. IAINU has the jargon of religious social entrepreneur which is manifested in the vision and mission and its implementation in the Tri Dharma of Higher Education, namely education, research, and community service. Based on the vision and mission, stakeholders are increasingly interested in and entrusting their sons/daughters to study at this institution.

IAI Tarbiyatut Thalabah Kranji Paciran Lamongan (hereinafter referred to as IAI TABAH) is an Islamic college that is located in a traditional Islamic boarding school foundation, but thanks to the support and efforts of the foundation's leadership in advancing the college, it is so high that the college has obtained permission to establish it. Islamic college 
with the name STAIDRA (Sunan Drajat Islamic High School) in 1995. Furthermore, due to higher public interest, and for institutional development, in 2014 it changed its shape to the Islamic Religious Institute. IAI TABAH has the jargon of being superior, religious, competitive which is manifested in the vision and mission and its implementation in every activity of the Tri Dharma of Higher Education.

This study uses qualitative descriptive approach, in which researchers collect data by face to face and interact with people in the study (Syamsuddin and Vismaia, 2007: 73). Qualitative research is a type of research whose findings are not obtained through statistical procedures or other forms (Strauss and Corbin, 2003: 73). There are two data sources in this study, namely the primary data source and secondary data source, the following is an explanation related to the two data sources; a). Primary sources, namely data obtained directly from the source, for example informants, social sites or events observed (Sukardi, 2008: 205). Primary sources in this research are rector IAINU Tuban and rector IAI TABAH Lamongan. Interview with these two rectors to obtain data related to the branding strategy used; and $b$ ). Secondary data sources, namely data or information obtained from other sources or have been processed by other parties, such as documents (Sukardi, 2008: 205). In this research, secondary data sources are college alumni, parent of student, public, and other documents related to research. Interview with this secondary data source to get data on stakeholders' views on the IAINU Tuban and IAI TABAH Lamongan brands.

Based on the background above, on this occasion the researcher raised the issue with the title "Islamic Higher Education Branding in The Coastal Area Perspective of Hermawan Kartajaya’s PDB Triangle Theory".

\section{B. Discussion}

\section{Branding Institutions in Private Islamic Higher Education}

Brand is a sign in the form of a picture, name, word, letters, numbers, color arrangement, or a combination of these elements that have the power of differentiation and are used in the activities of trading goods or services (Fandy Tjiptono, 2005: 2). This definition has similarities with the definition of the American Marketing Association version which defines the brand as a name, term, sign, symbol, design, or a combination of these, intended to identify goods or services to differentiate them from competing goods or services (Kotler and Keller, 2009: 332). 
Based on these two definitions, technically if a marketer creates a logo, or a new symbol for a new product, then he has created a brand (Kotler and Keller, 2009: 332). Products and brands in some literature are often interpreted the same, but basically products and brands are valued as two separate things, where the brand is a sign that is added to the product. Brands are seen as part of the product, so branding is considered as an activity that adds value to the product (Kotler and Keller, 2009: 330).

From some of the definitions above, it can be concluded that branding is the perception of stakeholders about a brand that is attached to the organization in accordance with their knowledge and experience of the brand.

\section{Benefits of Branding in Organizations}

An understanding of brand benefits cannot be separated from the main types of brands, because each type has a different brand image. The three types include: attribute brands, aspirational brands, and experience brands (Fandy Tjiptono, 2005: 21-22).

First, attribute brands, namely brands that have an image that is able to communicate confidence in the functional attributes of the product; Second, aspirational brands, namely brands that convey the image of the type of people who buy the brand concerned. The image is not much related to the product, but rather more related to the coveted lifestyle. The belief held by consumers is that by owning such a brand, a strong association will be created between him and certain groups, such as rich, prestigious and popular). In this case the status of social recognition and identification is far more important than just the functional value of the product; Third, experience brands, reflect brands that convey the association's image and emotions together (shared association and emotions). This type has an image beyond mere aspirations and is more related to the philosophical similarities between brands and individual consumers. The success of a brand experience is determined by the ability of the brand concerned in expressing individuality and personal growth.

In general, brands have multiple benefits, namely for organizations and stakeholders. For brand organizations, there are several benefits, namely: 1). Means of identification to facilitate the process of handling or tracking products for the organization; 2). A form of legal protection against unique product features or aspects. Brands can get intellectual property protection; 3). Signal the level of quality to satisfied stakeholders, so they can easily choose it another time; 4). Means of creating associations and unique meanings that differentiate products from competitors; 5). Sources of competitive advantage, especially through legal protection, stakeholder loyalty, and a unique image formed in the minds of stakeholders; 6). 
Sources of financial return, especially concerning future income (Fandy Tjiptono, 2005: 2122).

\section{Private Islamic Higher Education Institutions}

Understanding Higher Education (PT) is contained in PP No. 4 of 2014. As an education unit, $\mathrm{PT}$ is an autonomous and independent region that has the right to manage its own institutions as centers for the administration of higher education, scientific research, and community service. The purpose and objective of granting such autonomy is given in the context of developing science and technology, developing the potential of the academic community, and guided by the norms and rules of science itself (Serian Wijatno, 2009: 16).

According to the provisions of Law Number 4 of 2014 concerning the National Education System, Higher Education in Indonesia can be organized in the form of: Academies, Polytechnics, Colleges, Institutes, and Universities. Implementation of Higher Education in order to realize the goals of national education, needs to understand the nature of Higher Education as a whole because the PT entity has several dimensions of meaning, namely the ethical dimension, scientific dimension, educational dimension, social dimension, corporate dimension (R. Eko Indrajit \& Djokopranoto, 2006: 35-36). The following is an explanation of each dimension.

First, the ethical dimension. In the ethical dimension, Higher Education is called the center of creativity and the center of the spread of knowledge, not for the sake of creativity itself, but for the welfare of humanity. The essence of the task of Higher Education is to devote themselves to the research, teaching, and education of students. Higher Education is an academic community that carefully and critically helps protect and enhance human dignity and cultural heritage through research, teaching, and various services provided to local, national and even international communities.

Second, the scientific dimension. Higher Education is a collection of academic societies, namely the scientific community which has the autonomy of knowledge in the form of academic freedom in each discipline in accordance with their respective principles and methods.

Third, Education dimension. In the educational dimension, Higher Education becomes a place of education in the learning process that is not limited to the learning environment, but also outside the learning environment as a conscious endeavor of the learning process at the Higher Education. 
Fourth, social dimension. Higher Education prepares students to take responsibility in the community. From its graduates, the community expects continuous renewal and improvement in the governance of community and state life. Furthermore, Higher Education is expected to contribute in solving various problems that are being faced by the community, such as food shortages, unemployment, lack of health care, injustice and various other social problems.

Fifth, the corporate dimension. Higher Education provides services to the community in the form of higher education services in the form of learning and research processes. The main product of Higher Education is the knowledge provided to the public in the form of higher education services so that the main business of Higher Education is science. The main service users of tertiary institutions are students. In the form of Private Universities, students are the main source of funds in accordance with the status of the legal entity. So, the small number of students (not meeting quantitative product targets) will result in higher education institutions not being able to finance themselves and thus experiencing deficits. If it continues like this, the continuity of higher education will be threatened. Higher Education owns and manages a variety of sources, such as human resources, goods, finance, equipment, and methods. This shows the similarity with the corporation (R. Eko Indrajit \& Djokopranoto, 2006: 35-36).

\section{Strategies to Build Institution Branding with PDB Triangle by Hermawan Kartajaya}

Researchers use the theoretical foundation of building an institutional brand that is used in the business world, it is hoped that this strategy can be applied in the world of education. Namely building an educational organization brand using the PDB Triangle strategy. The following is a description of the PDB Triangle (Positioning, Differentiation, Brand). 


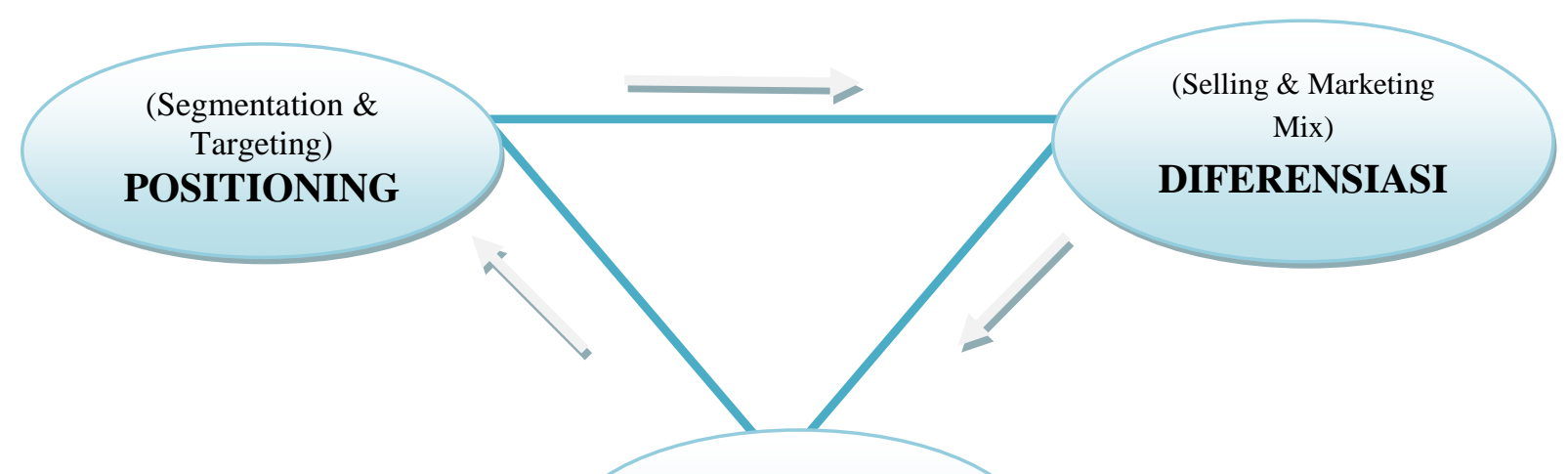

(Service \& Process)

BRAND

PDB Triangle (Positioning-Differentiation-Brand)

The strategy PDB Triangle consists of 3 concepts that make up a triangle, namely positioning, differentiation and brand. Before forming positioning, there are 2 strategies that precede, namely segmentation and targeting. From these two activities, it will be easier to determine a solid positioning, after the positioning is determined, then it will be realized by making a solid differentiation. From solid differentiation, which is able to prove positioning, the desired brand image is achieved.

\section{Segmentation (View Your Market Creatively)}

Segmentation is an element of strategic marketing that must be done properly by the organization, because it will relate to other marketing elements. Segmentation is also an important part of an institution's brand building strategy.

In order to operate effectively, the organization first needs to set its mission or "reason for being". In this mission, the organization needs to understand "What organization is it engaged in?". After establishing its mission and market, it is necessary to divide the market into smaller segments based on similar characteristics of stakeholder behavior, and then determine which segments will be served (Philip Kotler, Hermawan Kartajaya, Hooi Den Huan, and Sandra Liu, 2003: 52).

\section{Targeting (Allocate Your Resources Effectively)}

In general targeting is defined as the market selection process that the organization will aim at in offering a product or service (The Offical MIM Academy Coursebook, 2010: 10). Another definition states that targeting is a strategy to allocate limited resources effectively to the right target market through an evaluation process and determine which segments will be 
served, so the organization must review the potential of the target market (target market) in the future (Hermawan) Kartajaya, 2005).

Targeting is important for an organization, because stakeholders have diverse characters and needs, so they must be grouped in the smallest segments with the same character. On the other hand the organization has limited resources to offer to all markets, so the organization must sort out the right allocation of resources to the right market. This brings the conclusion that an organization must allocate resources effectively and efficiently to appropriate and potential market segments (The Offical MIM Academy Coursebook, 2010: 10).

\section{Positioning (Lead Your Customer Credibly)}

Positioning is a promise (Hermawan Kartajaya, 2005: 26). An action to design an organization's offer and image so that the organization can be in a meaningful competitive position and be in the minds of stakeholders (Philip Kotler, Hermawan Kartajaya, Hooi Den Huan, and Sandra Liu, 2003: 52). Another definition states that positioning is a process to place the organization in the minds of stakeholders. This definition means that the organization must have credibility so that the positioning of the organization can easily be embedded in the minds of stakeholders (The Offical MIM Academy Coursebook, 2010: 1920).

Positioning concerns how to build trust, confidence, and competence for customers. If the element is owned, then the organization has a "being" (being) in the minds of stakeholders. Therefore, positioning is called "being strategy". Positioning is about how organizations gain stakeholder trust to voluntarily choose the organization (Philip Kotler, Hermawan Kartajaya, Hooi Den Huan, and Sandra Liu, 2003: 59).

Positioning the organization in the minds of stakeholders is very important for the organization to be successful in winning competition. Organizations must be smart in positioning their products as something unique and valuable, so that the product / organization can get a place in the minds of stakeholders.

\section{Differentiation}

Differentiation in general has an understanding of how to create different organizational offerings than competitors. Philip Kotler defines differentiation as the differentiation of an organization's market offer to create superior stakeholder value (Philip Kotler, Hermawan Kartajaya, Hooi Den Huan, and Sandra Liu, 2003: 52). Whereas Hermawan Kartajaya defines differentiation as the process of integrating content, context, and 
infrastructure from what is offered to stakeholders. The process of integrating is done through the process of creating unique bids by concentrating on dimensions, content (what to offer), context (how to offer), and infrastructure (enabler) (The Offical MIM Academy Coursebook, 2010: 27).

Brand

An organization must think of its brand as: (1) product, (2) organization, (3) person, and (4) symbol. These perspectives differ, but the aim is to clarify, enrich and differentiate the brand's identity.

Brand identity (brand identity) can provide direction, purpose, and meaning of the brand itself. The brand association represents what it implies an organization's promise to stakeholders. The structure of brand identity is generally divided into two major parts, namely: a) Core identity, which is the core identity that escorts when a brand enters a new market. If the market accepts the brand based on the core identity offered, it can be said that the battle in the market has been won; b) Extended identity, which results in a focus on both the customer and the organization. Which includes extended identity are all elements of brand identity that are not included in the core identity, which are organized in groups that have meaning.

\section{Brand Image IAINU Tuban and IAI Tabah Kranji Paciran Lamongan in Key Stakeholder Perspective}

\section{Brand IAINU Tuban in key stakeholder's perspective}

In general, there are two features of the IAINU Tuban brand in the perspective of key stakeholders, namely: (1) Key stakeholders have a positive impression of IAINU Tuban (Fifin, personal communication); (2) Key stakeholders state that generally the IAINU Tuban brand is quite good (Yakup, personal communication).

While the perception of key stakeholders about STITMA Tuban, there are four, namely: (1) Rapid development (Dina, personal communication); (2) Good physical building shape (Ummu, personal communication); (3) Religious campus (Yudi, personal communication); (4) Campus of educators and prospective educators (Vita and Sulthoniyah, personal communication). As an explanation, we include in the following chart: 


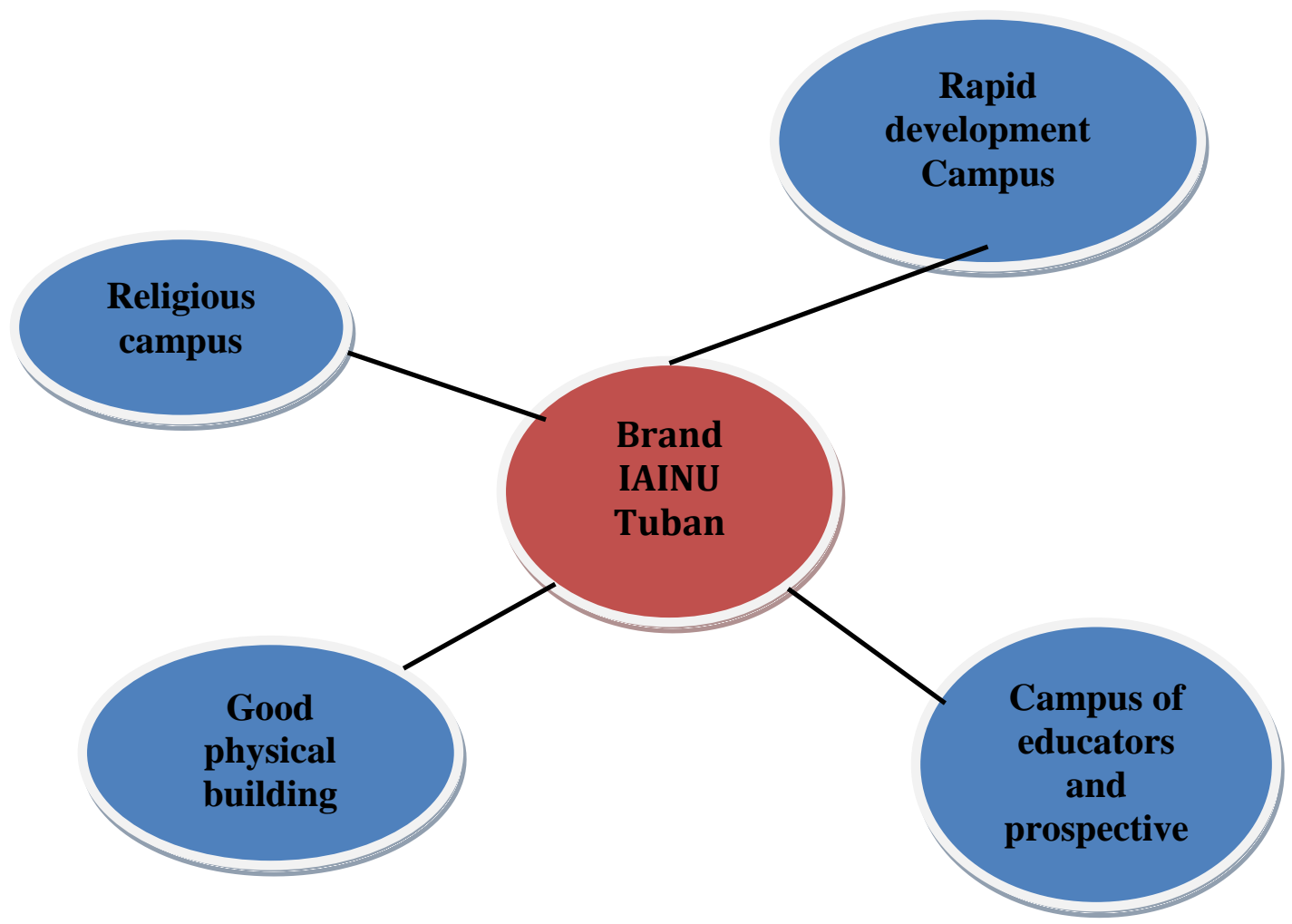

Brand IAINU Tuban in key stakeholder's perspective

\section{Brand Image IAI TABAH Kranji Paciran Lamongan in key stakeholder's perspective}

In general, there are three features of the IAI TABAH brand in the perspective of key stakeholders, namely: (1) Key stakeholders have known IAI TABAH Kranji since becoming STAI (Maslikah, personal communication), only one informant stated that he had not known Kranji IAI TABAH before (Sutrisno, personal communication); (2) Key stakeholders have a positive impression of IAI TABAH Kranji (Hadi, personal communication); (3) Key stakeholders state that in general the IAI TABAH Kranji brand image is quite good (Miftakhul, personal communication).

While the perception of key stakeholders about Kranji IAI TABAH, there are five, namely: (1) Rapid development (Amin, personal communication); (2) The existence of ma'had which supports the deepening of Islam (Yakup, personal communication); (3) The existence of tahfidz al-Qur'an scholarship (Fatkul, personal communication); (4) Has an Islamic label (Supriyanto, personal communication); and (5) Having an entrepreneur center (Ninik, personal communication). As an explanation, we include in the following chart: 


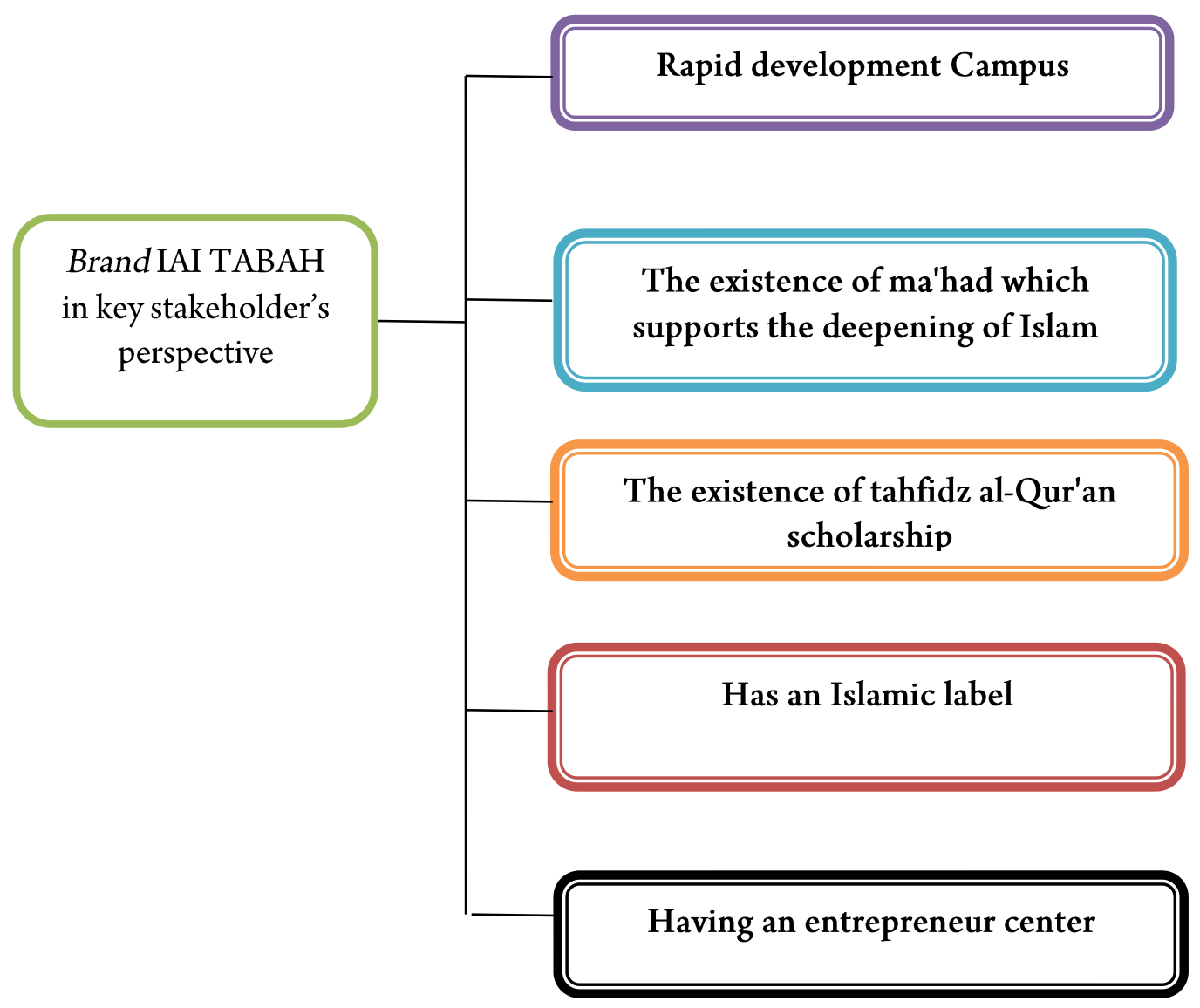

Brand IAI TABAH Kranji in key stakeholder's perspective

\section{Strategies to Build Brand IAINU Tuban and IAI Tabah Kranji Paciran Lamongan}

Strategies to build brand image IAINU Tuban

Based on the results of interviews with rector IAINU Tuban, we conclude that the strategies used in comparing campus are as follows:

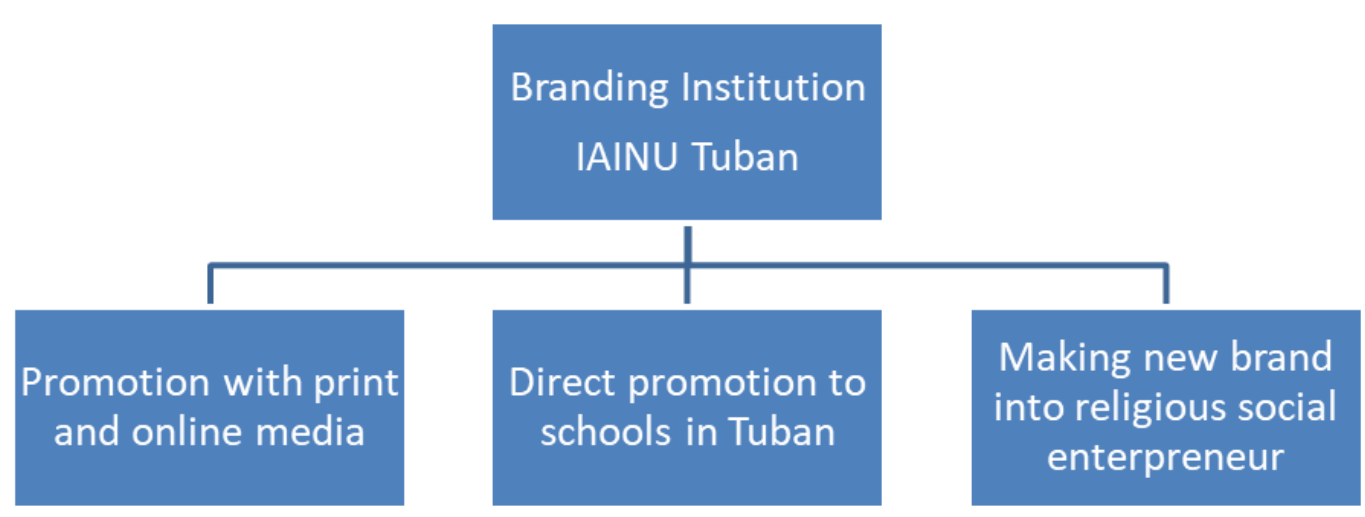


Based on this picture, it can be concluded that there are efforts made by the leaders of IAINU Tuban in branding their campuses, including: (1) Promotion with print and online media; (2) Direct promotion to schools in Tuban and surrounding areas; and (3) Making a new brand into a religious and entrepreneurial campus for educators and prospective educators.

\section{Strategies to build brand image IAI TABAH Kranji Paciran Lamongan}

Based on the results of interviews with the Chancellor of IAI TABAH Kranji, we conclude that the strategies used in building campus brands are as follows:

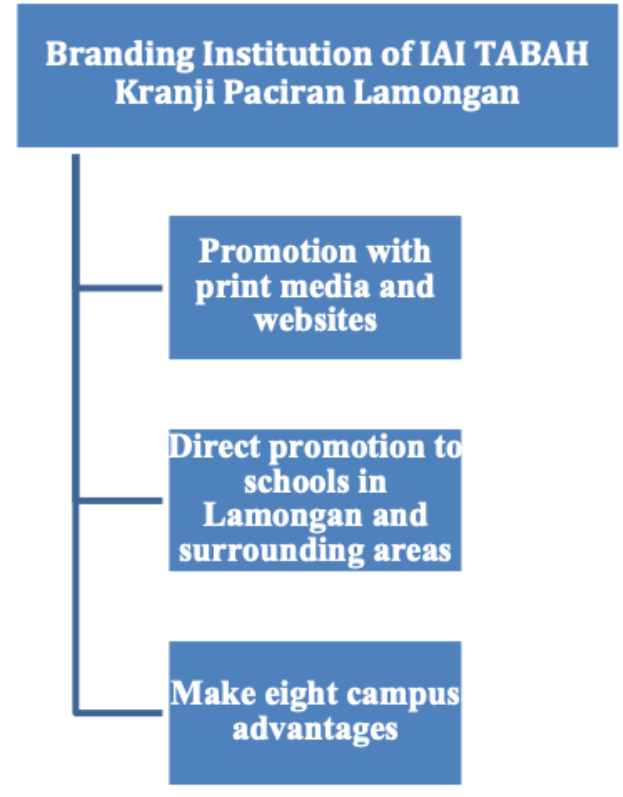

Based on the picture, it can be concluded that there are efforts made by the leaders of IAI TABAH in comparing campus, including: (1) Promotion with print and web media; (2) Direct promotion to schools in Lamongan and surrounding areas; (3) Making eight campus advantages, among others: First, the BAN-PT accredited study program; Second, qualified, competent, qualified S2 and S3 lecturers from reputable national and international universities; Third, air-conditioned lecture rooms and free WIFI; Fourth, proficient in reading Al-Qur'an at UMMI method; Fifth, There are Achievement scholarships, PEMKAB, and DIKTIS; Sixth, the study of the book of salaf; Seventh, Using the Participatory Action Research system; and Eighth, Enterpreneur center. 


\section{Conclusion}

Based on the results of information, data, findings and discussion, the results of this study can be concluded as follows: First, the IAINU Tuban brand and IAI TABAH Kranji Paciran Lamongan in the perspective of key stakeholders include: IAINU Tuban is characterized by; (1) Rapid and rapid development; (2) Campus of educators and prospective educators; (3) Physical appearance is quite good; (4) Religious campus. Whereas IAI TABAH Kranji Paciran Lamongan is characterized by: (1) Rapid and rapid development; (2) The existence of Islamic boarding schools which support the deepening of Islam; (3) The existence of tahfidz al-Qur'an scholarship; (4) Has an Islamic label; (5) Having an entrepreneur center.

Second, the strategies used by IAINU Tuban and IAI TABAH in building an institutional brand in accordance with the PDB Triangle Hermawan Kertajaya strategy are: (1) Positioning, which is done by clarifying campus icons; 2) Differentiation is making the campus characteristic, IAINU Tuban as a religious social entrepreneur campus and having the character of ahlussunnah wal jama'ah an nahdhiyah. Meanwhile, IAI TABAH Lamongan as a center for the development of Islamic science and competitiveness; 3) Brand is making the motto of each institution. The IAINU Tuban brand is a religious social entrepreneur, and the IAI TABAH brand is superior, religious, competitive. 


\section{REFERENCES}

Aaker, Building strong Brands, The Free Press: New York, 2010.

Abdullah, Kalthom, and Mohd Ismail Ahmad. "Compliance to Islamic Marketing Practices among Businesses in Malaysia.” Journal of Islamic Marketing 1, no. 3 (2010): 286-97. https://doi.org/10.1108/17590831011082446.

Abuznaid, Samir. "Islamic Marketing: Addressing the Muslim Market." An - Najah Univ. J. Res. (Humanities) 26, no. 6 (2012): 1473-1503.

Adnan, Ahmad Azrin. “Theoretical Framework for Islamic Marketing: Do We Need a New Paradigm?” International Journal of Business and Social Science 4, no. 7 (2013): 157-65.

Afifi, Subhan, and Edy Susilo. "Pengembangan Komunikasi Pemasaran Sekolah." Ilmu Komunikasi 13, no. 3 (2014): 277-86.

Ahmadova, Emiliya. "Islamic Marketing: The New Rules That Transform the Way of Conducting Business." Journal of Suleyman Demirel University Institute of Social Sciences 1, no. 2 (2016). https://doi.org/10.1108/17590831011055851.3.

Ahmed, Selim, and Habibur Rahman. "The Effect of Marketing Mix on Consumer Satisfaction: A Literature Review from Islamic Perspective.” Turkish Journal of Islamic Economics 2, no. 1 (2015): 17-30.

Alom, Mahabub, and Shariful Haque. "Marketing: An Islamic Perspective Alom \& Haque." World Journal of Social Sciences 1, no. 3 (2011): 71-81.

Alserhan, Baker Ahmad. "On Islamic Branding: Brands as Good Deeds." Journal of Islamic Marketing 1, no. 2 (2010): 101-6. https://doi.org/10.1108/17590831011055842.

Ambarsari, Dessy. "Strategi Pemasaran Untuk Perguruan Tinggi Di Indonesia." EKOMAKS; Jurnal Ilmu Ekonomi, Manajemen, Dan Akutansi 6, no. 1 (2017).

Andharini, Sri Nastiti, Dewi Nurjannah, and Eka Kadharpa. "Komunikasi Pemasaran Jasa Pada Pendidikan Tinggi di Malang.” Seminar Nasional Dan Gelar Produk, 2016, 585-91.

Arham, Muhammad. "Islamic Perspectives on Marketing." Journal of Islamic Marketing 1, no. 2 (2011): 149-64. https://doi.org/10.1108/17590831011055888.

Arisandy, Yosy. "Womanology Perspektif Islam (Strategi Pemasaran Pada Perempuan)." Jurnal Hawa 1, no. 1 (2019): 19-34.

Aziz, M. (2017). Strategi Pengelolaan Zakat Secara Produktif Pada Lembaga Amil Zakat dalam Tinjauan UU RI Nomor 23 Tahun 2011 Tentang Pengelolaan Zakat (Studi Kasus di Nurul Hayat Kantor Cabang Tuban Periode 2015-2016). Al Hikmah: Jurnal Studi Keislaman, 7(1). https://doi.org/10.36835/hjsk.v7i1.2536.

Aziz, M. (2019). Reconstruction of Maqashid Shari'ah Perspective Muhammad Thahir Ibn 
'Assyria: Efforts to Re-Discuss Sharia with Reality. JURNAL HUKUM ISLAM, , 231-249. doi:10.28918/jhi.v17i2.2396

Aziz, Muhammad; Sholikah, S. Zakat Profesi Dalam Perspektif UU RI Nomor 23 Tahun 2011 Dan Hukum Islam. ULUL ALBAB Jurnal Studi Islam, [S.l.], v. 15, n. 2, p. 188-205, mar. 2015. ISSN 2442-5249. Available at: <http://ejournal.uinmalang.ac.id/index.php/ululalbab/article/view/2665>. Date accessed: 09 mar. 2020. doi:http://dx.doi.org/10.18860/ua.v15i2.2665.

Azra, Azyumardi, Pendidikan Islam Tradisi dan Modernisasi Menuju Millennium Baru, Jakarta: logos Wacana Ilmu, 1999.

Al-'Atibi, Badr Mabruk. Taswiq al-Khidmat al-Jami'iyyah wa dauruhu fi tahsini al-qudroh attanafisiyyah li al-Jami'ah as-Su'udiyyah. Mutathollib takmily linaili darojati al-dukturoh fi Qismi idaroh at-tarbiyyah wa at-takhthith fi kulliyat at-Tarbiyyah fi Jami'ah Ummu alQuro As-Su'udiyyah, 2015.

Consoli, Domenico. "A New Concept of Marketing: The Emotional Marketing." BRAND. Broad Research in Accounting, Negotiation, and Distribution 1, no. 1 (2010): 1-8.

Creswell, John, Qualitative Inquiry and Research Design, Thousand Oaks, CA: Sage, 1997

Dewi Dirgantari, Puspo. "Peranan Bauran Pemasaran Jasa Pendidikan Terhadap Upaya Meningkatkan Ekuitas Merek Berbasis Pelangga Perguruan Tinggi." Strategic; Jurnal Pendidikan Manajemen Bisnis 11, no. 20 (2016): 22-31.

Faizin, Imam. "Strategi Pemasaran Jasa Pendidikan Dalam Meningkatkan Nilai Jual Madrasah.” Madaniyah 7, no. 2 (2017): 261-83.

Fakhrurozi. "Strategi Pemasaran Jasa Pendidikan Dalam Meningkatkan Citra Pendidikan Islam." Jurnal Pemikiran, Riset Dan Pengembangan Pendidikan Islam 7, no. 2 (2012): 207-32.

Fathoni, Muhammad Anwar. "Konsep Pemasaran Dalam Perspektif Hukum Islam.” Jurisdictie: Jurnal Hukum Dan Syariah 9, no. 1 (2018): 128-46.

Fauzi, Yayan. “Manajemen Pemasaran Perspektif Maqasid Syariah.” Jurnal Ilmiah Ekonomi Islam 1, no. 03 (2015). https://doi.org/10.29040/jiei.v1i03.51.

Herr, Paul, Higher Education Institutional Brand Value in Transition: Measurement and Management Issues, (Diakses melalui http://net.educause.edu/ir/library/pdf/ffp0104s.pdf ffp0104, pada 26 Maret 2011)

Kartajaya, Hermawan, on Brand, Bandung: Mizan, 2004.

Kotler dan Keller, Manajemen Pemasaran edisi 12 jilid 1, penerjemah: Benyamin Mollan, Jakarta: PT. Macana Jaya Cemerlang, 2009.

Kotler, Philip dan Gary Amstrong, Principles of Marketing, 13th. Upper Saddle River, NJ: 
Prentice. 2010

Kotler, Philip, dkk, Rethinking Marketing, Jakarta: Indeks, 2005

Marrs, Rachel, Musa, Utilizing Brand Audit to Develop University Brand: A Case Study, Journal ASBBS Annual Converence: Las Vegas, Vol. 18 No. 1, February 2011.

Prabowo, Sugeng Listyo, Manajemen Pengembangan Mutu Sekolah/ Madrasah, Malang: UIN Malang Press. 2008

Sholikah, S. (2015). Pendidikan Karakter Menurut K.H. Hasyim Asy'ari dalam Kitab Adâb al'Âlim wa al-Muta'allim. Maraji: Jurnal Ilmu Keislaman, 2(1), 117-143. https://doi.org/10.36835/maraji.v2i1.40.

Sholikah, S. (2017). Relevansi Kompetensi Pendidik Menurut K.H. Hasyim Asy'ari Dengan UU Sisdiknas Tahun 2003. Al Hikmah: Jurnal Studi Keislaman,7(1). https://doi.org/10.36835/hjsk.v7i1.3091.

Sholikah, S. 2015. Pendidikan Karakter Menurut K.H. Hasyim Asy’ari dalam Kitab Adâb al'Âlim wa al-Muta'allim. Maraji: Jurnal Ilmu Keislaman. 2, 1 (Sep. 2015), 117-143. DOI:https://doi.org/10.36835/maraji.v2i1.40.

Syamsuddin dan Vismaia, Metode Penelitian Pendidikan Bahasa, Bandung: Rosdakarya. 2007.

The Offical MIM Academy Coursebook, Brand Operation, Jakarta: Esensi, 2010.

Tjiptono, Fandy, Brand Management \& Strategy, Yogyakarta: Andi, 2005

Webometric, Top Universities Indonesia 2011. (Diakses melalui http://www.rankinguniversitiewebometrics.2011.com. pada 06 Maret 2011)

Wishman, Rex, Internal Branding: a University's most intangible asset, (diakses melalui http://www.brandchampionablog.com).

Wilson, Jonathan A.J. “The New Wave of Transformational Islamic Marketing Reflections and Definitions.” Journal of Islamic Marketing 3, no. 1 (2012): 5-11. 
